\title{
MICROPROPAGATION OF URGINEA MARITIMA (L.) BAKER S. STR.
}

\author{
ANNA STOJAKOWSKA. \\ Department of Phytochemistry, Institute of Pharmacology, \\ Polish Academy of Sciences, Smętna 12, 31-343 Kraków, Poland
}

(Received: October 19, 1990. Accepted: April 20, 1992)

\begin{abstract}
A method of micropropagation of Urginea maritima (L.) Baker s.str. (Liliaceae) by adventitious shoot formation was developed. Bulb scales and leaf fragments were used as primary and secondary explants, respectively. The most favourable for shoot regeneration were media: MS supplemented with BAP or kinetin (bulb scales) and medium C containing NAA along with BAP (leaf explants). No difficulties in rooting and adapting of plants to greenhouse conditions were observed.
\end{abstract}

KEY WORDS: Urginea maritima (L.) Baker s.str., Liliaceae, micropropagation, adventitious shoots, tissue culture

\section{INTRODUCTION}

Urginea maritima (L.) Baker Agg. (Liliaceae), is a Mediterranean plant whose medicinal properties are well known. The plant contains bufadienolide glycosides, of which proscillaridin A and scillaren A are used in the therapy of cardiac insufficiency.

Traditionally, this species has been divided into two varieties: white and red. At present, Urginea maritima (L.) Baker is postulated to be regarded as an aggregate species, within which a few taxons have already been distinguished, including Urginea maritima (L.) Baker sensu stricto. These taxons differ from one another in morphology, content of the respective bufadienolides, chromosome number and range of distribution (Hegnauer 1986, Krenn et al. 1989).

So far, few studies have been devoted to tissue culture of plants of this species; they chiefly concerned attempts to obtain a callus tissue and suspension cultures (Lutz 1970, Shyr and Staba 1976). However, the obtained tissue cultures showed slow growth and the lack of or decreased capacity for bufadienolide biosynthesis in comparison with the intact plant. There is sparse literature data on organogenesis in $U$. martima tissue cultures (Lutz 1970, Grari and Backhaus 1987). A closely related species is Urginea indica Kunth., for which a method of micropropagation by way of both organogenesis (Jha et al. 1984b, Somani et al. 1989) and somatic embryogenesis has been developed (Jha and Sen 1986).

The present paper was designed to determine a quick and effective method of "in vitro" propagation of the Urginea maritima (L.) Baker s.str. species, a hexaploid plant with a white bulb, found to occur in the Iberian Peninsula and characterized by a high content of pharmacologically active scillarenin-derived bufadienolides (Krenn et al. 1989).

\section{MATERIAL AND METHODS}

\section{PLANT MATERIAL}

Bulb scales of Urginea maritima (L.) Baker s.str. plants, were used to initiate a tissue culture. Secondary explants were fragments $(5 \times 12 \mathrm{~mm})$ of leaves of sterile plants, obtained in vitro from primary explants.

After removing outer scales, bulbs (ca. $3 \mathrm{~cm}$ in diameter) were washed and initially sterilized with $70^{\circ}$ ethanol for 10 min. Afterwards the bulbs were cut vertically into 6-8 segments, of which each contained part of the basal plate. The segments were sterilized with a $10 \%$ solution of Dimanin $\mathrm{C}$ preparation (Bayer) and rinsed four times with sterile distilled water.

\section{INDUCTION OF ADVENTITIOUS SHOOTS}

Primary explants (single bulb scales) were inoculated in Petri dishes on Murashige and Skoog's (MS) medium (1962) with added growth regulators, solidified with $0.6 \%$ Difco Bacto Agar, pH 6.0, before autoclaving. The auxins used were: 2,4-dichlorophenoxyacetic acid (2,4-D), 3-indoleacetic acid (IAA), $\alpha$-naphtaleneacetic acid (NAA); the cytokinins were: kinetin $(\mathrm{Kn})$ and 6-benzylaminopurine (BAP), used in the concentration ranges shown in Table 1 . The cultures were maintained at $25^{\circ} \mathrm{C}$ in two variants: (1) at constant illumination with luminescent lamps $(2000 \mathrm{~lx})$ and (2) in the dark. The explants were transferred to fresh medium every 5 weeks. Each treatment was done in replicate and 10 explants were used per treatment.

\section{SHOOT MULTIPLICATION}

Secondary explants (leaf fragments) were inoculated on a modified MS medium containing macronutrients at halfstrength. In order to determine the optimum concentration of growth substances for shoot multiplication, the medium was supplemented with: $0.5,1.0,2.0,4.0,8.0,16.0 \mathrm{mg} / \mathrm{dm}^{3}$ of BAP along with $1.0,2.0,4.0$, and $8.0 \mathrm{mg} / \mathrm{dm}^{3}$ of NAA in 24 combinations (each concentration of cytokinin with each concentration of auxin). The culture was kept at $25^{\circ} \mathrm{C}$ in the dark. The explants were transferred to a fresh medium every 4 weeks. Each treatment was raplicated and 10 explants were used per treatment. 
TABLE 1. Effect of different concentrations of growth regulators on the organ and callus formation from primary explants of Urginea martima (L.) Baker s.str. after 15 weeks od culture under continuous illumination (A) and in the dark (B)

\begin{tabular}{|c|c|c|c|c|c|c|c|c|c|c|c|c|c|}
\hline \multirow{3}{*}{\multicolumn{2}{|c|}{$\begin{array}{l}\text { Growth } \\
\text { regulator } \\
\text { added to } \\
\text { the medium }\end{array}$}} & \multicolumn{12}{|c|}{$\begin{array}{l}\text { Concentration of the growth regulator in the culture } \\
\text { medium }\left(\mathrm{mg} / \mathrm{dm}^{3}\right)\end{array}$} \\
\hline & & \multicolumn{2}{|c|}{0.1} & \multicolumn{2}{|c|}{0.5} & \multicolumn{2}{|c|}{1.0} & \multicolumn{2}{|c|}{2.0} & \multicolumn{2}{|c|}{4.0} & \multicolumn{2}{|c|}{8.0} \\
\hline & & A & B & A & B & A & B & A & B & $\mathrm{A}$ & B & A & B \\
\hline IAA & $\begin{array}{l}\mathrm{S} \\
\mathrm{R} \\
\mathrm{C}\end{array}$ & $\begin{array}{l}+ \\
+ \\
-\end{array}$ & $\begin{array}{l}+ \\
+ \\
-\end{array}$ & $\begin{array}{l}+ \\
+ \\
-\end{array}$ & $\begin{array}{l}+ \\
+ \\
-\end{array}$ & $\begin{array}{l}+ \\
+ \\
-\end{array}$ & $\begin{array}{l}+ \\
+ \\
-\end{array}$ & $\begin{array}{l}+ \\
+ \\
-\end{array}$ & $\begin{array}{l}+ \\
+ \\
-\end{array}$ & $\begin{array}{l}+ \\
+ \\
-\end{array}$ & $\begin{array}{l}+ \\
+ \\
-\end{array}$ & $\begin{array}{l}+ \\
+ \\
-\end{array}$ & $\begin{array}{l}+ \\
+ \\
-\end{array}$ \\
\hline NAA & $\begin{array}{l}\mathrm{S} \\
\mathrm{R} \\
\mathrm{C}\end{array}$ & $\begin{array}{l}+ \\
+ \\
-\end{array}$ & $\begin{array}{l}+ \\
+ \\
-\end{array}$ & $\begin{array}{l}+ \\
+ \\
-\end{array}$ & $\begin{array}{l}+ \\
+ \\
-\end{array}$ & $\begin{array}{l}+ \\
+ \\
-\end{array}$ & $\begin{array}{l}+ \\
+ \\
-\end{array}$ & $\begin{array}{l}+ \\
+ \\
-\end{array}$ & $\begin{array}{l}+ \\
+ \\
-\end{array}$ & $\begin{array}{l}+ \\
+ \\
-\end{array}$ & $\begin{array}{l}+ \\
+ \\
- \\
\end{array}$ & $\begin{array}{l}+ \\
+ \\
- \\
\end{array}$ & $\begin{array}{l}+ \\
+ \\
-\end{array}$ \\
\hline 2.4-D & $\begin{array}{l}\mathrm{S} \\
\mathrm{R} \\
\mathrm{C}\end{array}$ & $\begin{array}{c}+++ \\
+ \\
+\end{array}$ & $\begin{array}{l}+ \\
+ \\
+\end{array}$ & $\begin{array}{l}- \\
+ \\
+\end{array}$ & $\begin{array}{l}+ \\
+ \\
+\end{array}$ & $\begin{array}{l}- \\
- \\
+\end{array}$ & $\begin{array}{l}+ \\
- \\
+\end{array}$ & $\begin{array}{c}- \\
- \\
+++\end{array}$ & $\begin{array}{l}- \\
- \\
+\end{array}$ & $\begin{array}{l}- \\
- \\
+\end{array}$ & $\begin{array}{l}- \\
- \\
+\end{array}$ & $\begin{array}{l}- \\
- \\
-\end{array}$ & $\begin{array}{l}- \\
- \\
-\end{array}$ \\
\hline $\mathrm{Kn}$ & $\begin{array}{l}\mathrm{S} \\
\mathrm{R} \\
\mathrm{C}\end{array}$ & $\begin{array}{l}- \\
- \\
-\end{array}$ & $\begin{array}{l}+ \\
+ \\
-\end{array}$ & $\begin{array}{l}- \\
- \\
-\end{array}$ & $\begin{array}{l}+ \\
+ \\
-\end{array}$ & $\begin{array}{l}+ \\
- \\
-\end{array}$ & $\begin{array}{l}+ \\
+ \\
-\end{array}$ & $\begin{array}{l}+ \\
- \\
- \\
\end{array}$ & $\begin{array}{c}++ \\
- \\
-\end{array}$ & $\begin{array}{c}++ \\
- \\
- \\
\end{array}$ & $\begin{array}{c}+++ \\
- \\
-\end{array}$ & $\begin{array}{c}+++ \\
- \\
-\end{array}$ & $\begin{array}{c}+++ \\
- \\
- \\
\end{array}$ \\
\hline BAP & $\begin{array}{l}\mathrm{S} \\
\mathrm{R} \\
\mathrm{C}\end{array}$ & $\begin{array}{l}+ \\
- \\
- \\
\end{array}$ & $\begin{array}{l}+ \\
+ \\
-\end{array}$ & $\begin{array}{l}+ \\
- \\
- \\
\end{array}$ & $\begin{array}{l}+ \\
+ \\
-\end{array}$ & $\begin{array}{l}+ \\
- \\
-\end{array}$ & $\begin{array}{l}+ \\
+ \\
-\end{array}$ & $\begin{array}{c}++++ \\
- \\
-\end{array}$ & $\begin{array}{c}+++ \\
- \\
-\end{array}$ & $\begin{array}{c}+++ \\
- \\
- \\
\end{array}$ & $\begin{array}{c}+++ \\
- \\
-\end{array}$ & $\begin{array}{c}+++ \\
- \\
-\end{array}$ & $\begin{array}{c}+++ \\
- \\
-\end{array}$ \\
\hline control & $\begin{array}{l}\mathrm{S} \\
\mathrm{R} \\
\mathrm{C}\end{array}$ & $\begin{array}{l}+ \\
+ \\
-\end{array}$ & $\begin{array}{l}+ \\
+\end{array}$ & & & & & & & & & & \\
\hline $\begin{array}{l}\text { S - shoot } \\
\mathrm{R}-\text { root }\end{array}$ & rma & tion & & $\begin{array}{c}+ \\
++ \\
++ \\
++ \\
+++\end{array}$ & $\begin{array}{r}-u \\
-2 \\
-5 \\
+-m \\
\end{array}$ & $\begin{array}{l}-5 \mathrm{re} \\
-10 \mathrm{r} \\
\text { hore } t \\
\text { per e? }\end{array}$ & $\begin{array}{l}\text { ene } \\
\text { gen } \\
\text { an }\end{array}$ & $\begin{array}{l}\text { erated } \\
\text { nerate } \\
10 \text { re } \\
\text { nt }\end{array}$ & $\begin{array}{l}\text { lorga } \\
\text { ed or } \\
\text { egene }\end{array}$ & $\begin{array}{l}\text { ans p } \\
\text { gans } \\
\text { eratec }\end{array}$ & $\begin{array}{l}\text { ans pe } \\
\text { per ex } \\
\text { per e } \\
\text { d org }\end{array}$ & $\begin{array}{l}\text { er exp } \\
\text { xplan } \\
\text { expla } \\
\text { gans }\end{array}$ & $\begin{array}{l}\text { plant } \\
\text { it } \\
\text { ant }\end{array}$ \\
\hline $\begin{array}{ll}\mathrm{C} & -\mathrm{c} \\
+ & -\mathrm{v} \\
++ & - \\
+++ & -\mathrm{g}\end{array}$ & or & $\begin{array}{l}\text { forma } \\
\text { oor }\end{array}$ & tion & & & & & & & & & & \\
\hline
\end{tabular}

\section{ROOTING OF ADVENTITIOUS SHOOTS}

Regenerated shoots, more than $5 \mathrm{~cm}$ long, obtained from both primary and secondary explants, were placed on MS medium with macronutrients reduced by a half, free from growth regulators. After 2 weeks of culturing at $25^{\circ} \mathrm{C}$ under continuous illumination $(20001 \mathrm{x})$, rooting of $90 \%$ of plants was observed.

After the following 2 weeks the plants were transferred to pots with substrate consisting of sand, peat and soil (1:1:1, $\mathrm{v} / \mathrm{v})$, and were treated once with a $0.05 \%$ solution of Fongarid $25 \mathrm{NP}$ preparation (Ciba-Geigy) and left in the greenhouse.

\section{RESULTS AND DISCUSSION}

In vitro cultures of Urginea maritima (L.) Baker s.str. were initiated from bulb scales on MS media which contained different concentrations of auxins and cytokinins, under continuous illumination or in the dark. The MS medium supplemented with BAP $\left(2.0-4.0 \mathrm{mg} / \mathrm{dm}^{3}\right)$ or kinetin $(8.0$ $\mathrm{mg} / \mathrm{dm}^{3}$ ) (Table 1) was the most favourable for adventitious shoot formation. Using the above media, up to 20 shoots per explant were obtained (std.dev. no higher than 5.4) with no tendency to form roots.

Light had no significant influence on the number of shoots regenerated on the above media; however in the case of kinetin-containing media, better results were obtained in the dark. Under continuous illumination, root formation on media with low concentrations of cytokinins was inhibited. Low concentrations of NAA (up to $1.0 \mathrm{mg} / \mathrm{dm}^{3}$ ) only slightly stimulated regeneration of shoots, which subsequently formed roots. Control explants, as well as those cultivated on media with IAA, regenerated plantlets from fragments of the basal plate. In the case other growth hormones, except for 2,4-D, shoots were formed directly from the explant, first of all on the basal part of the scale and close to the cut site, then on the whole surface of the scale.

2,4-D was the only growth regulator promoting callus formation, which started from the wounded site. According to Kromer (1985), 2,4-D is the most effective growth substance for initiation of callus in some monocotyledonous plants. Calli obtained in our experiment differed morphologically. The callus formed in the light on a medium containing 0.1

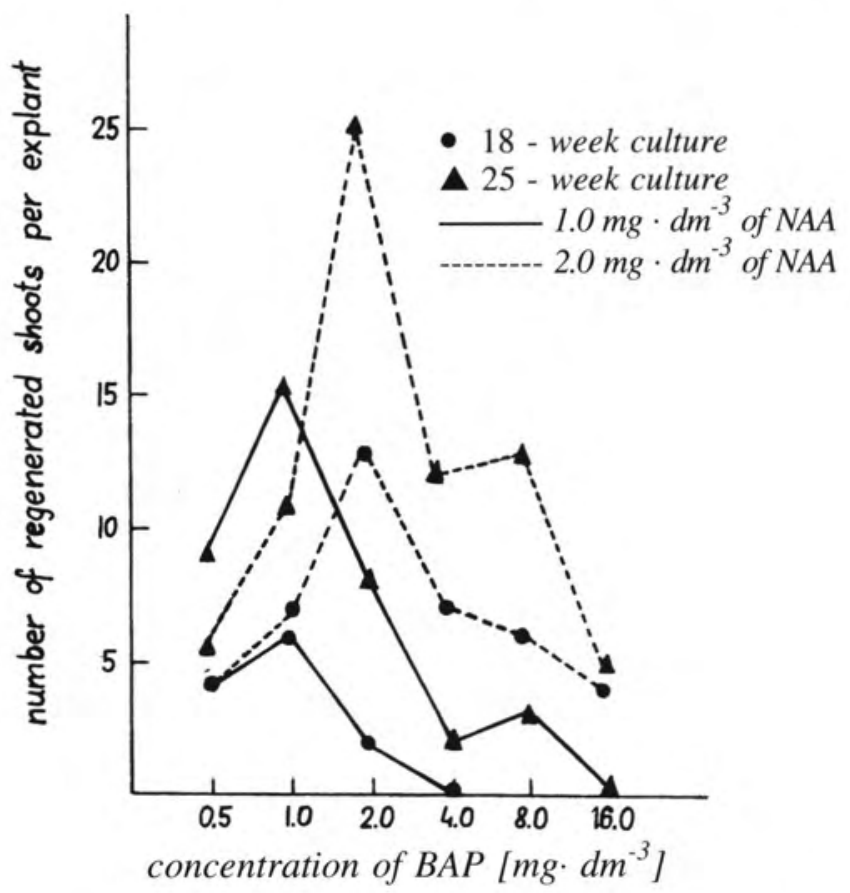

Fig. 1. The effect of BAP concentration in the nutrient medium, in combination with 1.0 or $2.0 \mathrm{mg} / \mathrm{dm}^{3}$ of NAA, on shoot formation after 18 and 25 weeks of culture of leaf explants

$\mathrm{mg} / \mathrm{dm}^{3}$ of 2,4-D was yellowish-green, compact and showed a tendency to form shoot buds, whilst that on a medium with $2.0 \mathrm{mg} / \mathrm{dm}^{3}$ 2,4-D was yellow, friable and remained undifferentiated throughout the culture.

The second stage of a micropropagation procedure is multiplication of shoots on secondary i.e. on fragments of leaves from sterile growing plants.

Three variants of culture media were chosen for the preliminary experiment of which only MS medium with 1.0 $\mathrm{mg} / \mathrm{dm}^{3}$ of NAA, $0.5 \mathrm{mg} / \mathrm{dm}^{3}$ of BAP and half-strength macronutrients yielded satisfactory results: about 10 shoots per explant were regenerated on that medium during 18 weeks of culture. To establish the optimum concentrations of growth regulators and auxin/kinin ratio, the nutrient medium containing BAP along with NAA in different concentrations was 
used as specified before. The average number of regenerated shoots per explant inoculated on media containing 1.0 $\mathrm{mg} / \mathrm{dm}^{3}$ of NAA together with $0.5-2.0 \mathrm{mg} / \mathrm{dm}^{3}$ of BAP or 2.0 $\mathrm{mg} / \mathrm{dm}^{3}$ of NAA along with $0.5-16.0 \mathrm{mg} / \mathrm{dm}^{3}$ of BAP exceeded 5 after 25 weeks of culture (Fig. 1). Shoots were regenerated indirectly from the callus tissue which emerged on the cut sites. High concentrations of the auxin in the nutrient medium - 4.0 and $8.0 \mathrm{mg} / \mathrm{dm}^{3}$ of NAA - inhibited shoot bud formation. Initiation of callus tissue was observed on media containing $4.0-8.0 \mathrm{mg} / \mathrm{dm}^{3}$ of NAA along with $0.5-2.0$ $\mathrm{mg} / \mathrm{dm}^{3}$ of BAP. However, the calli grew slowly and showed no tendency for organogenesis with the exception of callus obtained on the medium supplemented with $8.0 \mathrm{mg} / \mathrm{dm}^{3}$ of NAA and $0.5 \mathrm{mg} / \mathrm{dm}^{3}$ of BAP where roots with numerous hairs emerged.

Figure 1 shows the pattern of shoot regeneration on media containing 1.0 or $2.0 \mathrm{mg} / \mathrm{dm}^{3}$ of NAA along with $0.5-16.0$ $\mathrm{mg} / \mathrm{dm}^{3}$ of BAP. The highest number of shoots was obtained on media supplemented with either $1.0 \mathrm{mg} / \mathrm{dm}^{3}$ of NAA and $1.0 \mathrm{mg} / \mathrm{dm}$ of BAP or $2.0 \mathrm{mg} / \mathrm{dm}^{3}$ of NAA and $1.0-8.0$ $\mathrm{mg} / \mathrm{dm}^{3}$ of BAP (over 10 shoots per explant) (Fig. 2).

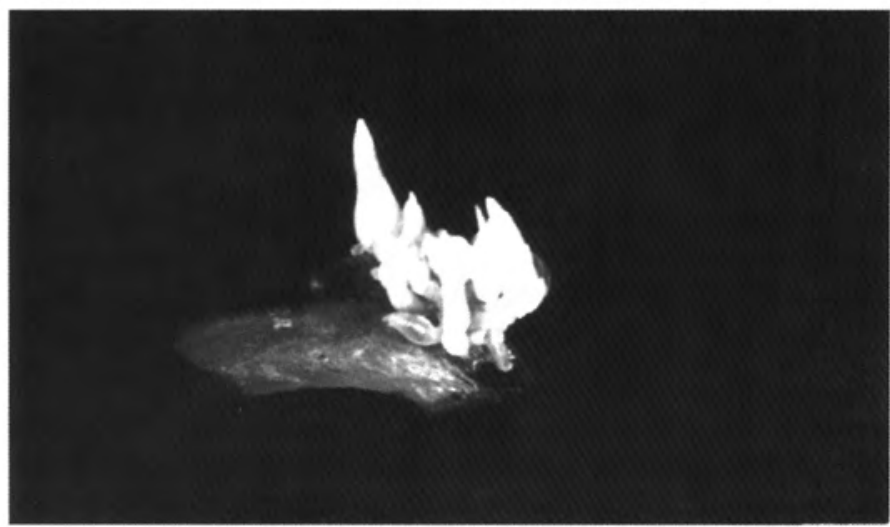

Fig. 2. Leaf explant of Urginea maritima after 18 weeks of cultivation on a modified MS medium (macronutriens reduced by one-half) containing $2.0 \mathrm{mg} / \mathrm{dm}^{3}$ of BAP and $2.0 \mathrm{mg} / \mathrm{dm}^{3}$ of NAA

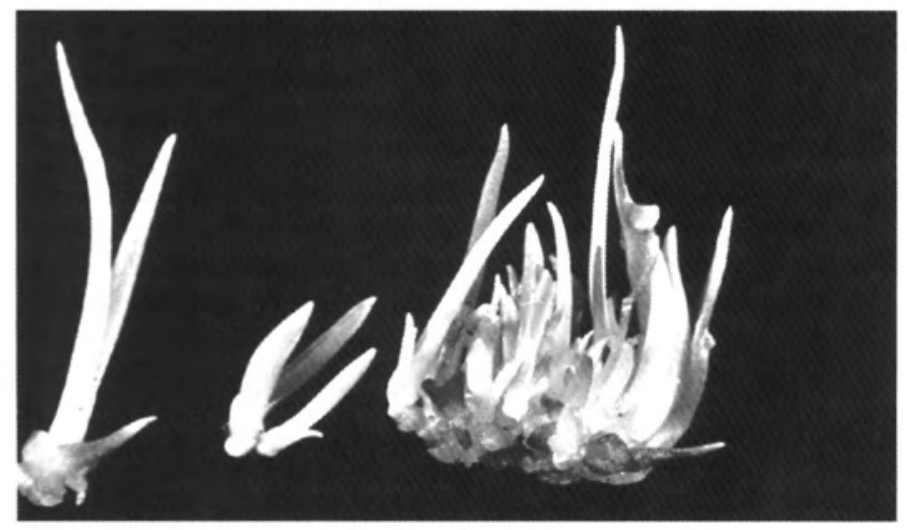

Fig. 3. Shoots regenerated from leaf explants of. $U$. maritima on the modified MS medium with $0.5 \mathrm{mg} / \mathrm{dm}^{3}$ of BAP and $1.0 \mathrm{mg} / \mathrm{dm}^{3}$ of NAA

Three generations of plants were derived following the described procedure. In the case of leaf explants obtained from every subsequent generation of plants the capability to form callus tissue decreased, though the average number of regenerated shoots remained the same. Unrooted shoots cultivated on media containing $1.0 \mathrm{mg} / \mathrm{dm}^{3}$ of NAA and $0.5-1.0$ $\mathrm{mg} / \mathrm{dm}^{3}$ of BAP showed a tendency towards multiplication. During 10 weeks of culture 2-5 new adventitious shoots were obtained in this way.

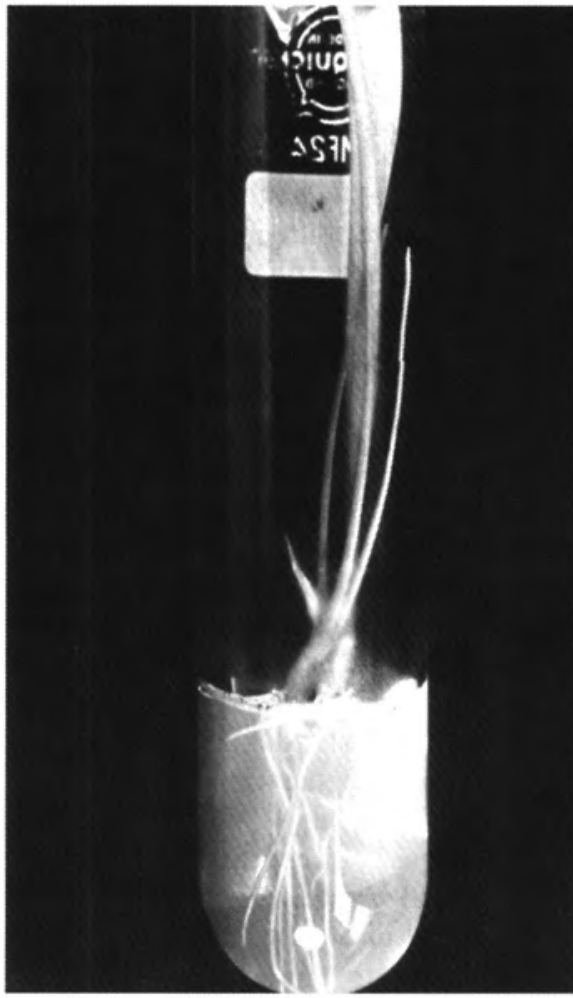

Fig. 4. Rooted $U$. maritima plants after 3 weeks of cultivation on hormone-free modified MS medium

Regenerated shoots (Fig. 3) were transferred to the hormone-free MS medium with macronutrients reduced by a half for rooting. Within 3 weeks of culture under continuous illumination, $90 \%$ of shoots formed 1-6 roots (Fig. 4). The roots were up to $7 \mathrm{~cm}$ long and had no laterals. In the case of shoots kept in the dark, formation of roots was poor and re-

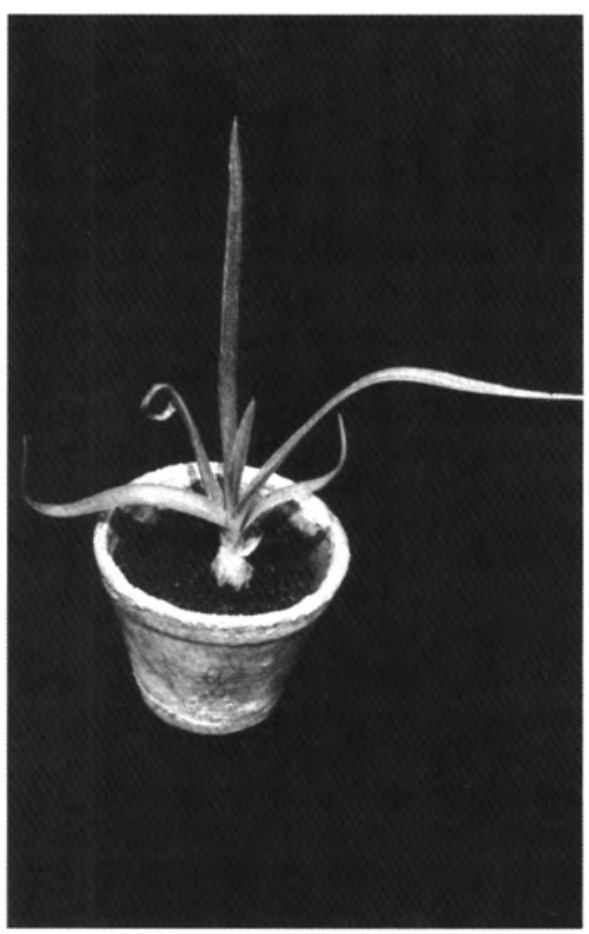

Fig. 5. Urginea maritima plant 7 months after transferring it to soil

quired more time.

Some of the regenerated plants were used as a source of secondary explants, and $80-90 \%$ of the others successfully adapted for growth in pots (Fig. 5). 
In vitro cultures of monocotyledonous plants show a very diversified response to exogenous growth regulators (Jha and Sen 1984). The same effect, e.g. shoot regeneration, is brought about by different culture conditions. This phenomenon in partly connected with levels of endogenous cytokinins and auxins, which differ according to genotype, organ, and growth stage of the plant used as the source of explants. Concentrations of growth regulators in nutrient media, required for organogenesis, vary widely and should be determined empirically for each species or even genotype (Hussey 1983, Rauber and Grunewaldt 1988).

This paper is the first to discuss in vitro propagation of $U r$ ginea maritima (L.) Baker s.str. The presented results indicate that exogenous cytokinin plays an important role in inducing shoot regeneration, as was in the case of some other monocots (Fridborg 1971, Heuser and Apps 1976, Hosoki and Asahira 1980). Somani et al. (1989) described a method of propagation of Urginea indica Kunth. by direct shoot regeneration from bulb explants, maintained on the MS medium containing kinetin. However, we found that BAP was more effective in inducing shoot regeneration from the primary explants. In contrast to Jha et al. (1984 a), who suggested that in the case of Urginea indica adventitious shoot formation could not be obtained directly from primary explants, regeneration was achieved in our experiment.

Hussey (1976) found that cytokinin had no effect on the direct formation of plantlets from explants and from the callus of Ornithogalum thyrsoides. Auxin alone stimulated direct plant regeneration from explants of some monocotyledons (Hussey 1975). Auxin was also used for plant regeneration in Urginea indica Kunth. (Jha et al. 1984) and Zephyranthes robusta Baker (Furmanowa and Olędzka 1981) tissue cultures. The medium containing auxin as the only growth regulator, which was used during our preliminary experiments, yielded no satisfactory results, though.

Some authors emphasize the synergistic action of exogenous cytokinin and auxin on shoot regeneration in tissue cultures of monocots. Kromer (1985) found that kinetin together with NAA, IAA or 2,4-D stimulates shoot bud formation to a greater extent than kinetin alone. Hussey and Falavigna (1980) observed that the most favourable medium for adventitious shoot formation in Allium cepa L. was the medium containing BAP along with NAA. Our results confirm the assumption that a combination of the two growth substances most favourably induces shoot regeneration from leaf explants of Urginea maritima s.str.. Grari and Backhaus (1987), who investigated the in vitro propagation of red squill - Urginea maritima Agg. var. rubra, observed a positive effect of both NAA and BAP on bulblet regeneration on bulb explants cultivated in the dark. In contrast to the latter authors, we found that regeneration of shoots on bulb explants occurs both in the dark, as well as under continuous illumination; furthermore, we observed no difficulties in rooting of the shoots regenerated from either primary or secondary explants. Those authors' statement that the rooting of shoots requires a medium supplemented with NAA and is inhibited by light has not been confirmed, either.

The rooting of shoots of monocots is often spontaneous, occurring simultaneously with shoot regeneration, and does not need any special procedure (Furmanowa and Olędzka 1981, Kromer 1985). In other cases, media which are hormone-free or contain a low concentration of auxin are used for this purpose (Hosoki and Asahira 1980, Jha and Sen 1984 b).
The most favourable medium for shoot regeneration from bulb scales (primary explants) of Urginea maritima (L.) Baker s.str. is the MS medium with an addition of 2.0-4.0 $\mathrm{mg} / \mathrm{dm}^{3}$ of BAP.

In the case of leaf explants (secondary explants) the most advantageous rate of multiplication was observed on the MS medium with macronutrients at half-strength, supplemented with 1.0 or $2.0 \mathrm{mg} / \mathrm{dm}^{3}$ of NAA, along with $0.5-1.0$ and $1.0-$ $8.0 \mathrm{mg} / \mathrm{dm}^{3}$ of BAP, respectively.

The rooting of shoots occurs on a hormone-free or auxincontaining media and is stimulated by light.

Rooted plants can easily be adapted to growth in the soil under greenhouse conditions.

\section{ACKNOWLEDGEMENTS}

This study was carried out within project CPBR 3.13.6..Partial results were presented at the $47^{\text {th }}$ Conference of the Polish Botanical Society, Łódź 1986, and at the Satellite Symposium of CPT 89 - Medicines of Plant Origin in Modern Therapy, Prague 1989.

\section{LITERATURE CITED}

FRIDBORG G., 1971. Growth and organogenesis in tissue cultures of Allium cepa var. proliferum. Physiol. Plant. 25: 436-440.

FURMANOWA M., OLĘDZKA H., 1981. Plant regeneration from excised bulb scale segments of Zephyranthes robusta Baker. Acta Soc. Bot. Pol. 50: 399-404.

GRARI R.E., BACKHAUS R.A., 1987. In vitro propagation of red squill, Urginea maritima Baker. Plant Cell Tissue Organ Cult. 10: 65-71.

HEGNAUER R., 1986. Chemotaxonomie der Pflanzen. Birkhauser Verlag, Basel. Vol. 7, pp. 691-693.

HEUSER C.W., APPS D.A., 1976. In vitro plantlet formation from flower petal explants of Hemerocallis cv. Chipper Cherry. Can. J. Bot. 54: 616-618.

HOSOKI T., ASAHIRA T., 1980. In vitro propagation of Narcissus. HortScience, 15: 602-603.

HUSSEY G., 1975. Totipotency in tissue explants and callus of some members of the Liliaceae, Iridaceae, and Amaryllidaceae. J.Exp. Bot. 26: 253-262.

HUSSEY G., 1976. Plantlet regeneration from callus and parent tissue in Ornithogalum thyrsoides. J. Exp. Bot. 27: 375-382.

HUSSEY G., 1983. In vitro propagation of horticultural and agricultural crops. In: Plant biotechnology. Mantell S.H., Smith H. (ed.). Cambridge University Press, Cambridge, pp. 111-138.

HUSSEY G., FALAVIGNA A., 1980. Origin and production of in vitro adventitious shoots in the onion, Allium cepa L.. J. Exp. Bot. 31: 1675-1686.

JHA S., MITRA G.C., 1984 a. In vitro regeneration from bulb explants of Indian squill, Urginea indica Kunth. Plant Cell Tissue Organ Cult. 3: 91-100.

JHA S., SEN S., 1984 b. Morphogenesis and propagation of medicinally important plant species of family Liliaceae; A review. NSABMATP (Bot. Lab: Pharm. Anat.) (Calcutta. Univ.); pp. 89-100.

JHA S., SEN S., 1986. Development of Indian squill (Urginea indica Kunth.) through somatic embryogenesis from long-term culture. J. Plant. Physiol. 124: 431-439.

KRENN L., KOPP B., KUBELKA W., 1989. Content and composition of bufadienolides in species of the Urginea maritima aggregate. Planta Med. 55: 624.

KROMER K.D., 1985. Regeneration of some monocotyledonous plants from subterranean organs in vitro. Acta Agrobot. 38: 65-87.

LUTZ U., 1970. Gewebekulturen von Urginea maritima. Dissertation zur Erlangung des Doktorgrades an der Philosophischen Fakultat der Universität Wien. 
MURASHIGE T., SKOOG F., 1962. A revised medium for rapid growth and bioassays with tobacco tissue culture. Physiol. Plant. 15: 473-497.

RAUBER M., GRUNEWALDT J., 1988. In vitro regeneration in $\mathrm{Al}$ lium species. Plant Cell Rep. 7: 426-429.
SHYR S.E. STABA E.J., 1976. Examination of squill tissue cultures for bufadienolides and anthocyanins. Planta Med. 29: 86-89.

SOMANI V.J., THENGANE S., JOHN C.K., THENGANE R.J., 1989. Micro-propagation in diploid Indian squill (Urginea indica Kunth.). Curr. Sci. 58: 201-204.

MIKROROZMNAŻANIE URGINEA MARITIMA (L.) BAKER S. STR.

\section{STRESZCZENIE}

Opracowano metodę mikrorozmnażania gatunku Urginea maritima (L.) Baker s.str. (Liliaceae) (nazwa polska: cebula morska, cebulica morska, ostrawka względnie oszloch morski, odpowiada gatunkowi zbiorowemu - Urginea maritima (L.) Baker Agg.), z eksplantatów pierwotnych - łusek cebulowych i wtórnych - wycinków liści roślin uzyskanych in vitro. Najlepsze rezultaty, w przypadku łusek cebulowych, otrzymano stosując pożywkę Murashige-Skoog'a, zawierającą $8,0 \mathrm{mg} / \mathrm{dm}^{3}$ kinetyny lub 2,0 - 4,0 mg/dm ${ }^{3}$ BAP. Natomiast z eksplantatów wtórnych, największa ilość pędów przybyszowych regenerowała na pożywce MS, w której zawartość makrolelementów zmniejszono o połowę, z dodatkiem 1,0 mg/dm ${ }^{3} \mathrm{NAA}$ i $0,5-1,0 \mathrm{mg} / \mathrm{dm}^{3}$ BAP lub $2,0 \mathrm{mg} / \mathrm{dm}^{3} \mathrm{NAA}$ i $1,0-8,0 \mathrm{mg} / \mathrm{dm}^{3}$ BAP. Uzyskane pędy oddzielono od tkanki macierzystej i ukorzeniono na pożywce MS (makroelementy zredukowane o połowę), pozbawionej regulatorów wzrostu. W ciągu 3 tygodni $90 \%$ pędów regenerowało korzenie. Rośliny łatwo adaptowały się do warunków szklarniowych.

SŁOWA KLUCZOWE: Urginea maritima (L.) Baker s. str., Liliaceae, mikrorozmnażanie, pędy przybyszowe, kultura tkankowa 